\title{
Jimma Town: Foundation and Early Growth from ca. 1830 to 1936
}

\author{
YONAS SEIFU* - JAN ZÁHOŘÍI** \\ *Department of History and Heritage Managment \\ Jimma University, Jimma, Ethiopia \\ yseifubuno@gmail.com \\ ** Department of History \\ University of West Bohemia, Pilsen, Czech Republic \\ nvgogol@seznam.cz
}

\begin{abstract}
This study deals with the early history of Jimma town and its growth from its foundation until 1936. It explores social, economic and administrative themes, but also attempts to show the interrelationship between these themes. The town of Jimma evolved during this period from being the home-town of a relatively homogenous society and culture into a place of residence for a diverse and increasingly cosmopolitan population. Economically, the story of Jimma during this period is one of both continuity and change. It is a story of continuity because Jimma, which had been a center of trade from the very beginning, continued to be so during this period. There was significant change, however, because unlike the previous decades in which Jimma had served as a point of exchange or transit for elite goods that mostly originated from beyond the borders of the Oromo Kingdom (such as slaves, ivory and musk), during this period the town developed into the chief center for the collection, organization and export of a cash crop that was grown locally (coffee).
\end{abstract}

1 This study is a part of SGS-2016-049 research grant.

DOI: 10.2478/eas-2018-0003 C University of SS. Cyril and Methodius in Trnava. All rights reserved. 


\begin{abstract}
Economic change, therefore, resulted in both production and exchange. The social, economic and administrative history of Jimma is closely intertwined, however. The mixture of peoples and cultures, as well as the nature of the urban social institutions that evolved in the town, are closely tied to "the cash crop revolution", which brought streams of permanent and temporary residents to the town; the evolution of the town into a chief administrative center, as well as the introduction of somewhat peculiar administrative and fiscal institutions, came about, at least in part, as a result of the location of the town in the heart of the "coffee country", as southwestern Ethiopia came to be known. In short, both the urbanity and the urbanization of Jimma can be explained by the story of coffee production and trade. This article documents these processes extensively and accounts for the growth of a major town in modern Ethiopia.
\end{abstract}

KEY WORDS: Jimma, Ethiopia, trade, urbanization, coffee, slavery

\title{
Introduction
}

Studies on the urbanization of Africa have shown that the continent has a long tradition of urban development. Many of the ancient African urban centers were chiefly the product of internal development. Some of them evolved as terminal points for caravan trade routes, developing, in some cases, as entrepots for inter-regional and international longdistance trade. Others served as the important political and administrative centers of various empires. Most urban centers, however, served multiple purposes, functioning as centers of administration and commercial activity, as well as points of transshipment and religious worship (BAIROCH 1998:28).

The growth of African towns accelerated during the colonial period. Colonial rule led to the emergence of new towns and to the revival of many old ones. The needs of the colonizers for improved transport and colonial administrative control fostered the growth of towns. These towns were mostly located in coastal areas, providing access to raw materials in the hinterland and manufactured goods from Europe. In some parts of Africa, due to the development of agricultural exports on the one hand and the massive influx of European colonists on the other, a number of urban centers were created. Furthermore, some European settlements gradually evolved into urban centers, and other types developed as the result of specific economic activities such as cash crop production and coal mining (LITTLE 1974:409-411).

The existing literature asserts that the process of modern urbanization in Ethiopia began to take shape from the latter part of the $19^{\text {th }}$ century. The territorial expansion of Menelik 
(r. 1889-1913), political stability and the effective centralization and bureaucratization of government brought relative acceleration to the pace of urbanization in Ethiopia, while the construction of the Addis-Ababa-Djibouti railway and the improvements in the system of transportation and communication are identified as factors that contributed to this new phase of urban development. Shoan expansion to the south led to the appearance of garrison centers, which eventually evolved into permanent, small-sized provincial towns. The garrisons were established either on already existing settlements or on fresh sites. Geographically, they were located on hill tops (DAMTE 1993:61-64).

Socially, they served mainly as permanent residences for the naftagnas (as northern and central Ethiopian settlers came to be referred to collectively). Some studies on urbanization in Ethiopia suggest that the emergence of the present towns in western and southwestern Ethiopia owes much to politico-military factors, i.e., to the establishment of military garrisons. It is true that many towns in western and southwestern Ethiopia developed historically from garrisons, but many of the garrisons were also abandoned when their military needs declined (WOLDE MICHAEL 1973:1-4).

A careful review of the historical records suggests that there were some important centers that predated the campaigns of Emperor Menelik. One of these settlements was the present Jimma town (GEMEDA 1989:32). In the history of urbanization in western and southwestern Ethiopia, the history of Jimma town is somewhat different. It combines three elements which none of the other urban centers in southern Ethiopia exhibit. First, it was an urban center that was built on indigenous origins. Second, it emerged as a chief administrative center for the whole of southwestern Ethiopia. Third, its growth and internal character came to be closely intertwined with the development of coffee production and trade. In fact, only a few cites in Africa (Kano, in Northern Nigeria is one example) have had such a history of connectedness with both indigenous and external dynamics. The aim of this article is to place the growth and development of Jimma town into the broader perspective of trade, urbanization and power relations in Ethiopia. The study is based on a number of primary sources primarily from the $19^{\text {th }}$ century as well as existing research by either Ethiopian or European researchers both published and unpublished. 


\section{Early days of Jiren, Hirmata, and Jimma}

Jimma is both the name of the town on which this study focuses, as well as being one of the five "Gibe states" that flourished in the second half of the $19^{\text {th }}$ century. The site of the present town was also a central market town in that kingdom and a staging point for caravans that traversed the whole length of the Ethiopian Highlands, all the way from Kaffa to Massawa. Political, economic and religious developments in the kingdom had important influences on the early urbanization process that characterized the town. Therefore, it is important to briefly consider the political, economic and religious history of the kingdom in relation to the evolution of Jimma town. Trade and trade routes have made a significant contribution to the evolution of towns in Ethiopia since ancient times. This is also true of southwestern Ethiopia. Not only was the region connected to the main route-way to the Red Sea, but was also an important source of lucrative commodities. Despite political ups and downs and regional variations in relation to stability, commercial interaction had continued between the northern and southern regions of Ethiopia for many hundreds of years. Ethnically, the term Jimma Oromo refers to all the Oromo of the Gibe, but originally it designated only five clans (gosa), the descendants of Jimma Sirba, who arrived and settled the Jimma area (ABREHAM 2012:21). According to some sources, the basis of Jimma town was put in place during the reign of Abba Magal (1787-1827), who shifted the political center from Kiftana to Hirmata and then to a place called Kimle Gando, where his grave still exists (SEMMA 2007:8). His son, Abba Rago (1827-30), built another palace in Hirmata but due to his inability to lead the assemblies of elders and notables he was forced to resign. Then, his son, Sanna, took a monarchical name, Abba Jifar I, and the period that was to see the rise of Jimma had begun (SEMMA 2007:9).

Jimma is one of the biggest and most important towns in Ethiopia and served as a significant market center in the area of South-West Ethiopia from the $19^{\text {th }}$ century, most notably in the Gibe Valley. The urbanization process in Jimma is relatively recent but in comparison with the rest of Ethiopia it is not exceptional as urbanization generally came to many parts of what is now Ethiopia over the past couple of centuries. The region of the Gibe Valley witnessed, mainly in the $19^{\text {th }}$ century, remarkable progress related to the formation of the state between the Didessa and Omo rivers. Five monarchies were inhabited by the Oromo people, then labelled as the Galla. These five monarchies were Jimma Kaka (later Jimma Abba Jifar), Gera, Guma, Goma, and Limmu Enarea. Obviously, we do not know the exact dates of the establishment of these entities but it is believed that the first signs of political unification and hereditary power were known in the second 
half of the $18^{\text {th }}$ century (ABIR 1965:206). While the northern parts of Ethiopia that formed the ancient Aksum kingdom, and later the Abyssinian state, were known to the rest of the world via numerous items and the accounts brought back by travelers to Europe and the Middle East (SALVADORE 2010: 593-627), written sources on the early history of Ethiopia south of Addis Ababa are less common. In this chapter, we do not have the space to reconstruct the history of the Jimma kingdom but it has to be stated that the most important event occurred in 1833 when Abba Jifar became the Abba Dulla of Hirmata, one of the tribes of the Jimma principalities, and came up with the plan to unify all the Jimma tribes, which within a few years materialized into the kingdom of Jimma Abba Jifar (ABIR 1965:215-216). Immediately after this initial success it became clear that the interests of Jimma and Enarea were divergent and this resulted in wars between the two throughout the 1830s and 1840s (ABIR 1965:217). Charles T. Beke refers in 1843 to the need for a union to be accomplished through means of marriage and Islam as a way of establishing peace between the quarrelling parties of this region. Abba Jifar, according to his accounts, had a much better reputation among merchants than his rival Abba Bogido from Enarea, and this can be seen as one of the factors that stimulated the further growth of Jimma Abba Jifar (BEKE 1843:254-269).

The $19^{\text {th }}$ and $20^{\text {th }}$ centuries, of course, are the most well-documented, and the place of Jimma in the commercial history of Ethiopia is well attested. A.W. Hodson, for instance, reports that much of Jimma's trade was carried out by the native traders who went as far as Gardula in the south and Genir in the east (HODSON 1970:145). To the north, Jimma traders went to the Soddo markets and traded with Harari merchants (ABIR 1968:92). As a result of the expansion in the volume of trade, the kingdom of Jimma developed into a nodal point out of which a number of routes radiated and on which they converged. The growth in the network of trade was accompanied by the emergence of important market centers in southwest Ethiopia. Among these local centers of trade, the most famous were Bonga (in Kaffa), Saqqa (in Limmu), and Hirmata (in Jimma). These market towns, located on the busy long distance trade routes, also served as political centers. They had both administrative and economic significance. Bonga was the capital of the Kingdom of Kaffa and the biggest center of exchange in that kingdom. From Bonga, all kinds of merchandise, including ivory, civet and spices, originated. The importance of trade in Bonga had attracted the Jabarti traders from the north, the Omotic traders from the south and the surrounding Afkala traders (Oromo merchants) (HASSEN 1990:136). 
Saqqa was the other commercial center which developed in the Gibe region prior to Menelik's conquest of southwest Ethiopia. It emerged both as a capital of the kingdom of Limmu Enarya and as a local market during the $19^{\text {th }}$ century (GEMEDA 1989:30; HASSEN 1990:136). It was the 'greatest emporium in the region up to the 1850s' (HASSEN 1990:135). Mohammed Hassen states that the Oromo state of Limmu Enarya promoted trade by protecting and encouraging long distance merchants and local traders. In the mid-19 ${ }^{\text {th }}$ century, Saqqa had already become a major commercial center between Kaffa and the other Oromo monarchies of the Gibe valley on the one hand and Guduru, Gojjām, Gondar and other locations in the north on the other. By the third quarter of the $19^{\text {th }}$ century, however, Ennarya's economic predominance in the region was effectively challenged by Jimma Kaka (GEMEDA 1989:30).

Jimma Kaka, one of the five Gibe Oromo monarchies, came into existence in the second half of the $18^{\text {th }}$ century (GEMEDA 1989:32). The core of the monarchy was Hirmata, a small Oromo principality ruled by an enterprising warrior called Abba Magal. Around the beginning of the $19^{\text {th }}$ century, Abba Magal initiated a series of campaigns against his neighbors and achieved the territorial expansion of the principality. The territorial expansion of Abba Magal was further advanced by his successors. It was particularly during the reign of Abba Jifar I, (ca 1830-1854) that most of the territories of the Kingdom were conquered. In 1830, Abba Jifar became the first king (moti) of the Kingdom (BEKE 1843:43). A well-organized political establishment, a good endowment of economic resources, and its strategic location on the main long distance trade route leading into southwestern Ethiopia, all helped the state of Jimma to quickly become the most powerful state in the region. According to Cardinal Massaja, Jimma Kaka had about 150,000 inhabitants in 1861 (MASSAJA 1889:6). The so-called Gibe Valley states were incorporated into Ethiopia at the end of the $19^{\text {th }}$ century during Menelik II reign. Jimma Abba Jifar, however, was able to retain its autonomy up until the 1930s. The army of Abba Jifar was composed mostly of Amhara soldiers, who were hired from Gojjam and other northern parts of Ethiopia (CAULK 1978:470).

\section{Market in Jiren}

Its geographical limits were the Omo River in the east and south, Mount Botor in the north and the mountains of Limmu and Gomma in the north and west. Jiren was the political 
center of Jimma and the main seat of its rulers. It was founded during the reign of $A b b$ Jifar I. Jiren was selected also for its strategic location and elevation (2,020 $\mathrm{m}$ above the sea (evel), which made it possible to monitor possible enemy movements in the area. Initially, Jiren consisted almost entirely of the masara (palace) of Abba Jifar I and the residences of his courtiers. However, it quickly grew into the "heart of the kingdom, the center from which orders radiated to the boundaries and to which great wealth flowed" (LEWIS 1965:68). Not long after the establishment of the court, there emerged in Jiren a small bi-weekly market, held on Mondays and Fridays. The market attracted people from the surrounding rural areas. In due course, the market became a small village consisting of a number of houses and a large number of residents. According to Pankhurst, Jiren's trade was "carried out not in the immediate vicinity of the palace, but at a market an hour's ride away" (PANKHURST 1982:315), in Hirmata, named after an Oromo tribe. At the market, farmers brought their agricultural products to exchange them for small finished goods and implements. The importance of Jiren grew even more during the reign of Abba Jifar II. The Moti constructed an elaborate one-story palace and a number of mosques at Jiren According to informants, the palace was built by a team that included several foreigners. Between Jiren and Hirmata was a settlement called Mandara Seto, allocated to traders from outside the Jimma kingdom. They were under the direct supervision of the king as they were of crucial importance for the whole kingdom. The settlement of Mandara stood on a small hill and was divided into several quarters for merchants coming from different regions of what is now Ethiopia (PANKHURST 1982:316).

The locality of Jiren was already in a complex settlement by the late 1880 s. Leonardo Traversi witnessed hundreds of free servants, eunuchs, slaves and concubines in Jiren which was at that time divided into several quarters according to origin of its inhabitants. Each quarter had its own streets and was protected against wild animals. According to Traversi's observation, the riches of Jimma lied in slave trade (TRAVERSI 1888:907-910).

At the very beginning of the $20^{\text {th }}$ century, the German explorer Oscar Neumann visited Jimma on his journey from the Somali coast through Ethiopia to the Sudan. As he observed, "Jimma is almost the richest land of Abyssinia; the inhabitants are pure, wellbuilt Galla; they are nearly all Mohammedans, as is their king, Abba Jifar, a very clever man, who submitted to Menelik at the right time and, therefore, retained his country" (NEUMANN 1902:390). Neumann observed that the Thursday market in Jiren was visited by something between twenty and thirty thousand people from all the regions bordering the river Omo, and even from Addis Ababa (NEUMANN 1902:390).

DOI: 10.2478/eas-2018-0003 C University of SS. Cyril and Methodius in Trnava. All rights reserved. 


\section{Process of incorporation into Ethiopian Empire}

The militia forces organized by Abba Jifar II early in the $20^{\text {th }}$ century were partly responsible for the increase in the population of Jimma. The "army" consisted of two main divisions: the Qawe Jabarti and the Kortawe. The Qawe Jabarti was largely composed of soldiers recruited from among the Gondare, Gojjame and Tigrian adventurers. They were estimated to number between 800 and 1,000. They had their own azazh (head) by the name of fitawrari Balachew. The Kortawe were made up of local militia, who served the court on a shift basis (GWYNN 1911:21).

After Jimma's incorporation into the Ethiopian Empire, soldiers of the central government also passed through the state on their way to such places as Kaffa, Bench, Maji and llubabor. This by itself necessitated the development of facilities for their reception, further enhancing the growth of the area that would later become Jimma town.

Prior to the Italian invasion, the Kingdom/province of Jimma had developed into an important center of Muslim learning in southwestern Ethiopia. According to Mohammed Hassen, by the end of $19^{\text {th }}$ century there were about sixty or so Madrasas (schools for Islamic learning) in Jimma, mostly located in and around Jiren. A large number of students came to Jimma from the surrounding areas. Besides being the political center and or commercial emporium of the region, the function of the town as a center of Islamic learning and culture had attracted a considerable population from different parts of the country (HASSEN 190:15). Jules Borelli witnessed two mosques and several sheikhs in Jiren at the end of the $19^{\text {th }}$ century. Mosques were constructed as simple huts (BORELLI 1889:267). However, Paul Kratzman, in a biography of Johann Ludwig Krapf, writes about an evangelization campaign taking place as far as Jimma: “Upon the advice of Dr. Krapf the Swedish National Missionary Society began work among the Galla tribe, and subsequently in the Kunama country, in northwestern Abyssinia, their chief station being Tendur. In 1870 they were forced to retire to Massowa, where they opened a school. Subsequently, they founded stations further inland, and three natives who had been trained by the missionaries pushed straight across the country to the Galla tribe in the province of Jimma, where they commenced the work of evangelization" (KRETZMANN 1900:155).

As suggested above, the other important quarter of Jimmā town was Hirmata. Jiren and Hirmata flourished together respectively as administrative and commercial centers. Hirmata came into existence before Jiren. It is said that Hirmata had been an important site for social activity ever since the occupation of the area by the Mecha Oromo in the 
early $17^{\text {th }}$ century. The term Hirmata comes from "Hirmachu" (Oromo: sharing) and indicates that the connection with the place was that the Mecha "shared cattle and other booty [at the site] after major raiding campaigns." Guluma Gemeda has collected and recorded similar traditions. He states that "some of the spoils [of war] were exchanged for other commodities at the same place, thereby probably giving rise to a small-scale market" (GEMEDA 1989:32).

The presence of Hirmata prompted the establishment of Jiren as one of the main political centers of the kingdom. This was because the leaders were interested in controlling the market at Hirmata. At the same time, the emergence of the kingdom enhanced the development of Hirmata as a principal center of trade. According to contemporary sources, Hirmata was overshadowed by Saqqa up to the beginning of the 1850s. Limmu Ennarya declined militarily and commercially from about the middle of the $19^{\text {th }}$ century, mainly owing to the expansion of Jimma under Abba Jifar I. As a result of this development a large number of Jabarti traders abandoned Saqqa in favor of Hirmata. It is also said that Abba Jifar I invited a number of Muslim clerics to evangelize freely in his domain in order to attract Muslim traders. Abba Jifar "embraced Islam for political and economic motives, rather than for religious needs" (HASSEN 1990:112).

\section{Commerce and Administration}

Jimma's commercial pre-eminence was further secured after the military success of Abba Jifar I against the neighboring local leaders of Yem and Badifola in 1844 and 1847 respectively. The victory of Abba Jifar assured his control over an important caravan route between Jimma and the northern markets. As a result, the commercial superiority of Saqqa rapidly dwindled and the center of exchange shifted to Hirmata. Thus, in the second half of the $19^{\text {th }}$ century, Hirmata became the most important center of trade in the Gibe region. In the market of Hirmata there were sections for handicrafts, agricultural goods, and livestock products (FULE 1985:38-59; HASSEN 1990:183-184). The most common items in the local market during this early period were grains and flour, honey, livestock and livestock products, handicraft products such as baskets, spear heads, plough heads, iron axes, sickles, knives, saddles, shields, belts, bags and pottery products such as pitchers, incense burners, coffee cups, milk containers etc. Items which were part of the long distance trade included musk, hides, ivory, and small quantities of coffee. Ivory, musk 
and spices mainly came from Kaffa. Manufactured products, such as perfumes, drugs and rifles, articles of clothing, such as Abujadid and a red woolen cloth known as Abukoton, colored silks, muslin (shashi), different curtains, trousers, and coats, were brought from Addis Ababa and sold in Hirmata and the surrounding markets (HASSEN 1990:140; NASSIR 1973:30-40). Gruhl referred to Hirmata as "the greatest [market] in all southern Abyssinia" (GRUHL 1932:146) and also noted that the market was organized after "the fashion of the great European markets." The sheer size of the market impressed Gruhl, who estimated that it was visited by eight to ten thousand customers on a good day (GRUHL 1932:155). Citing the British war office report of 1922, Richard Pankhurst has raised the figure to 30,000 . Hirmata was renowned also as a distribution point for salt, which came from the Taltal plains in Tigray (PANKHURST 1982:251). Northern traders coming from Gojjam, Shewa and Tigre, collectively known as nagadde, brought salt bars and thalers to Hirmata. Iron, which was produced in Jimma, was taken as far as Bale, via Hirmata (ABIR 1966:3).

Administratively, Jimma during this period developed from being the ruling center of a local dynasty that exercised authority over a small kingdom into the capital of a whole region. The background for this was set by the ending of the autonomous political existence of the Oromo Kingdom of Jimma and its full absorption into the political economy of the Ethiopian state on the eve of the Italian occupation of 1936. But the decision by the Italians to make Jimma the chief center of their activities in the whole of southwestern Ethiopia was of even greater significance. The imperial system of administration that was put in place after Liberation simply built on these early beginnings. According to several authors, e.g. Peter Garretson, the slave trade in the area between the Omo River and Jimma had been flourishing until the Italian occupation (GARRETSON 2002:206). When a Russian officer, Alexander Bulatovich, visited Southern Ethiopia at the very end of the $19^{\text {th }}$ century, he observed that when "the slave trade was suppressed by Menelik, under pain of death, Jimma was one of the main centers of this business, and its prosperity was dealt a considerable blow. The Emperor likewise made it a criminal offense to turn convicts into slaves" (BULATOVICH 2000:194).

Resident European and Arab merchants were also involved in the Jimma trade in the early $20^{\text {th }}$ century. In 1910, for instance, three of the most important foreign traders were reported to have been a Swiss by the name of Dubail, a Syrian called Ydlibi, and a French man called Guigniony. A. W. Hodson, the British officer who visited Jimma in 1917, also noted the existence of a number of British Indian subjects in the town. The Indian, Arab 
and occasionally Greek entrepreneurs operated firms in Hirmata that were engaged in the business of collecting hides, coffee, wax and the like (HODSON 1970:146).

As has been stated above, Hirmata's significance arose primarily from its strategic location. It was located at the juncture of the main long-distance trade routes to and from southwestern Ethiopia. Hirmata thus connected the trade of the region with the rest of the Ethiopian region. By the beginning of the $20^{\text {th }}$ century, however, the Jimma area had started to benefit greatly from coffee being produced for export. Coffee attracted both Ethiopian and foreign entrepreneurs, who began to operate from the town (GRUHL 1932:146). George Montadon traversed the country in 1912 and observed that "Hirmata is the great market of Jimma, the most important, in fact, of the whole South-West of Abyssinia. [...] As elsewhere in the Galla countries, hides, wax, coffee, ivory, and caoutchouc are the articles of export with which the representatives of European houses (which have here their remote agencies) concern themselves" (MONTADON 1912:375). The expansion of coffee cultivation eventually made not just Jimma but also the southwestern region as a whole among the most economically valuable parts of Ethiopia. The large-scale exploitation of coffee for commercial purposes, however, does not seem to have been well established before the third decade of the $20^{\text {th }}$ century. Improvements in the means of transportation, i.e., the opening of the Gambela water transportation system and the Addis Ababa-Djibouti railway system, facilitated the growth of coffee production and trade in southwest Ethiopia. Coffee was exported eastwards to the Gulf of Aden ports and, after 1907, westwards by boat from Gambela via the Nile to Khartoum in the Sudan. After about 1920, it was exported eastwards by railway to Djibouti (GEMEDA 1989:36; PANKHURST 1968:431-451). Originally, the railway was to be built in three directions, the first connecting Djibouti and Harar, the second from Harar to Entoto, and the third from Entoto to Kafa. Due to combination of various factors this plan was changed and what emerged was the famous Addis Ababa-Djibouti railway (WOLDE MICHAEL 1973:11).

Political stability and the effective organization of the administration during the reign of Abba Jifar II expedited commerce in Jimma. Local administrators provided protection for trade and traders in different market places. Sited at the four corners of Jimma, there were gates (kella) at which incoming and outgoing traders were inspected and taxed. These kellas carried the names of the regions or states that bordered on Jimma. Thus, there were gates leading to Dawero, Kaffa, Limmu and Shawa. There were officials known as Abba Kella (chief of the kella), who guarded the gates and ensured the security of 
traders that passed through them. The Abba Qoros (provincial governors) of all the sixty provinces also had an obligation to safeguard traders against mistreatment, robbery and attack (GOSHU 1970:14; GEMEDA 1989:36).

The favorable political and economic conditions in Jimma enhanced commercial activities in the town and attracted more merchants from Shawa, Gojjam, Gondar and Tigray in the north. Due to these factors, a traveler, Vanderheym, referred to inhabitants of Jimma as "traders and hard-working" people (VANDERHEYM 1896:123). As Jiren and Hirmata developed as political and commercial centers of the kingdom respectively, a third quarter, Mandara, was growing up between the two centers. Mandara, which in literal Oromiffa means "village", was from the very beginning a residential quarter for longdistance traders and their agents who traded at Hirmata. The diverse origins of these merchants were illustrated on the ground by the fact that their settlements came to carry the names of their places of origin. Thus, there was Mandara Wollo, Mandara Gojjam, Mandara Gondar, etc.

A small local market, (qocci in Oromiffa) also emerged in the area, providing for the daily needs of the significant resident community of traders and agents in Mandara. There were a considerable number of Arab, Syrian, Indian and Armenian commercial firms in and around qocci (GRUHL 1932:146-147).

After the 1920s, Mandara began to decline in importance and was overshadowed by Hirmata. This was probably because of the ever-widening scope of trade in Hirmata. The expatriate as well as local merchants of Mandara transferred their headquarters to Hirmata. By the early 1930s, except for a few huts and houses in which a small number of non-trading residents lived, Mandara had almost been abandoned. The fate of Jiren was similar. The political and administrative center of the Diggo rulers started to die a natural death with the erosion and final ending of Jimma's autonomy. The official agreement between Menelik and Abba Jifar II in 1882 had formalized the position of Jimma as a state tributary to Shawa. Throughout the reign of Menelik, Jimma had remained as a semiautonomous province in the Ethiopian Empire (GEMEDA 1989:34). This was the result of Abba Jifar's services and the annual payment of a heavy tribute. By services we mean Abba Jifar's willingness to place certain leaders of the formerly independent Oromo kingdoms (Gomma, Gera, Guma, and Limmu-Enarya) in custody and hold them as hostages against the good behavior of their kinsmen (CAULK 2002:204). 
During the 1920s, and early 1930s, a continuous process of administrative reorganization and the centralization of government and taxation was being advanced by Ras Tafari (later to become Emperor Haile Selassie). During this time, Jimma continued to flourish as a center of commerce. The economic importance of Jimma "necessitated in particular a greater control of the hitherto autonomous province". In the late 1920s, Ras Tafari took control of Jimma's customs service. Tafari appointed officials to collect market dues at Jimmā. Nagadras Sahla Eshete became the first Shoan official to be sent with a considerable number of soldiers and stationed at Hirmata in 1932. He was responsible for awarding "licenses" to merchants and for collecting taxes from the market. In 1932/33 dajazmach Wolde Amānuel was appointed by the Emperor as the first governor of Jimma. With him were a large number of troops, administrative personnel, judges and priests. Most of the newcomers, particularly the customs officials, established residences in what is presently known as Shawa gate (WOLDE MARIAM 1984:47; GEMEDA 1984:169).

After the death of Abba Jifar II in 1934, Jiren's importance completely declined. It lost its significance and most of its residents flocked to Hirmata, where they continued their engagement in the field of commerce. Despite their varying fortunes at various points in time, it is true that the morphology of the present Jimma town originated from these quarters, Jiren, Hirmata and Mandara, which served as centers of administration, exchange and merchant residence respectively. But it was the Hirmata market which grew into a viable quarter at the time of the relative decline of Jiren and on the eve of Italian occupation. The number of settlers in Hirmata increased and the size of the market grew. The volume of goods also expanded. Generally, the early history of the town of Jimma fits in with the general feature of African urbanization during the pre-colonial period. Towns emerged mostly as seats of local rulers and/or as market places (MABOGUNGE 1968:28).

From the preceding discussion, it is reasonable to conclude that the evolution of Jimma was interwoven with the growth of markets and the development of long distance trade on the one hand and the political consolidation of Jimma as a state on the other. In 1933 Haile Selassie took over the lead role in directing Jimma's internal affairs from Abba Jobir, the grandson of Abba Jifar II. Even if the local rulers were not totally deprived of their political influence, their role in administrative, political and economic matters became negligible. For their part, they were very upset about the new administrative and taxation system that was imposed on Jimma. The leading member of Jimma's ruling family on the eve of the Italian invasion was Abba Jobir. He is alleged to have sent a declaration to the Italian government accepting Italian sovereignty over Jimma. Because of this he was 
apparently imprisoned for a year at Akaki and for an additional year and a half in Manz. He was later freed and joined the Italians (SBACCHI 1985:130-136). Once Abba Jobir submitted to Graziani, he cooperated with the Italians in the conquest of southwest Ethiopia. Abba Jobir, who remained loyal to Italy to the very last, was promoted to the titular position of Sultan. Furthermore, he was regarded as "one of the most important Moslem leaders" and paraded as "an indication of Italy's good disposition toward the Muslims of Ethiopia" (ZEWDE 1991:162). In the same year, 1933, the government of Ethiopia completed the first all-weather road connection between Addis Ababa and Jimma in order to increase the export of coffee, the most crucial commodity (McCANN 1995:173). The importance of roads as a significant factor contributing to trade had already been witnessed by Bulatovich at the end of the $19^{\text {th }}$ century: "The duty to maintain the roads is considered very serious. Each land owner is entrusted, under penalty of serious punishment (in former times that could even mean being sold into slavery) with the obligation to keep the road in order" (BULATOVICH 2000:195).

After Italian sovereignty over Ethiopia became "legal" in May 1936, the Fascist government reconstituted an Italian Colonial Empire known as Africa Orientale Italiana, AOI (otherwise known as Italian East Africa). The Empire, which was formed by the fusion of a newly conquered Ethiopia with Italian Somalia and Eritrea, had six major regional divisions: Tigre, Amhara, Oromo-Sidama, Addis Ababa (later known as Shawa), Harar and Somalia. The respective capitals of these regions were Asmara, Gondar, Jimmā, Addis Ababa, Harar and Mogadishu.

Jimma, previously known as Hirmata and Jiren, thus became the capital of the "OromoSidama" region, one of the six administrative regions created by the Italians. This helped Jimma to emerge as one of the administrative centers and one of the biggest towns in Ethiopia. It appears that the loyalty of local rulers and the relatively easy "pacification" of the region had provided the Italians with a good opportunity to focus on construction. They invested significantly in infrastructure, such as buildings and roads. It was during this period that Jimma came to take on its present shape (GEMEDA 1989:38).

\section{Conclusion}

From 1936 to 1941, after losing the Italo-Ethiopian war that began in October 1935, Ethiopia was occupied by Italy. Remnants of Italian Fascist colonial architecture and DOI: 10.2478/eas-2018-0003 C University of SS. Cyril and Methodius in Trnava. All rights reserved. 
material culture can be seen in many parts of Ethiopia, not only in Addis Ababa, but also in very remote areas such as Benishangul-Gumuz (GONZÁLES-RUIBAL 2011:547-574). Even in the period immediately before the Italian occupation, Jimma had witnessed significant development. Shortly after the end of Italian colonial expansion in 1941, land was expropriated from local Oromo Muslims, just like in other regions of Ethiopia. As elsewhere in urban areas, a new middle class, composed mostly of government administrators, usually Amhara and Oromo Orthodox Christians from the Shawa region, emerged in Jimma (MAINS 2012:7). Jimma had already become part of international business activities by the first decades of the $20^{\text {th }}$ century and it is well-documented that by 1918 some of the larger foreign firms that had bases in Addis Ababa had established branches in Jimma as well (PANKHURST 1968:399). By the mid-1930s, shortly before the Italian invasion, there were some fifty firms with branches in Jimma and almost one hundred foreigners lived there, comprising primarily Greeks, Indians, and Arabs (PANKHURST 1968:446). The growth of Jimma town resembled in many ways the urbanization process in other regions of the country. Such towns as Dembi Dollo, Nekemte, or later Dire Dawa, emerged as important market centers, situated at the crossroads of the trade routes which connected trading centers and peripheral regions.

\section{Bibliography}

ABIR, M. (1968): Ethiopia: Era of the Princes. London: William Clowes and Sons Limited.

ABIR, M. (1965): The Emergence and Consolidation of the Monarchies of Enarea and Jimma in the First Half of the Nineteenth Century. In. Journal of African History 6, 2, pp. 205-219.

ABIR, M. (1966): Salt, Trade and Politics in Ethiopia in the Zemene Mesafint. In Journal of Ethiopian Studies 4, 2, pp. 1-10.

ABREHAM, A. (2012): Narrating Local Identity among the Southwestern Oromo of Ethiopia: Case of the Jimma and Gera. In. African Study Monograph 33, 1, pp. 17-47.

ADEM, A. (1992): Qubba Abba Arabu. An Islamic Shrine in Jimma. B.A. thesis. Addis Ababa: Addis Ababa University. 
BAIROCH, P. (1998): Cities and Economic Development: From the Dawn of History to the Present. Chicago: University of Chicago.

BEKE, C. T. (1843): On the Countries South of Abyssinia. In Journal of the Royal Geographical Society of London 13, pp. 254-269.

BEKE, C. T. (1851): Journey to Kaffa. London: James Madden and Leudenhall Street.

BORELLI, J. (1889): Ethiopie méridionale: journal de mon voyage aux pays Amhara, Oromo et Sidama, septembre 1885 à novembre 1888. Paris: May et Monteroz.

BULATOVICH, A. (2000): Ethiopia through Russian Eyes. Country in Transition 18961898. Transl. by Richard Seltzer. Lawrenceville: Red Sea Press.

CAULK, R. A. (1978): Armies as Predators: Soldiers and Peasants in Ethiopia, ca. 1850-1935. In International Journal of African Historical Studies 11, 3, pp. 457-497.

CAULK, R. A. (2002): "Between the Jaws of the Hyenas." A Diplomatic History of Ethiopia (1876-1896). Wiesbaden: Harrasowitz Verlag.

DAMTE, A. (1993): Urbanization in Ethiopia; Pre and Post Revolution Experience. Ph.D. thesis, Madison: University of Wisconsin.

DONHAM, D. - JAMES, W. (eds.) (2002): The Southern Marches of Imperial Ethiopia. Oxford: James Currey, pp. 196-217.

FULE, G. (1985): The Kingdom of JanJero: A Historical Survey to 1894. B.A. thesis. Addis Ababa: Addis Ababa University.

GARRETSON, P. P. (2002): Vicious cycles: ivory, slaves, and arms on the new Maji frontier. In

GEMEDA, G. (1989): "An Outline of the Early History of Jimma Town". In Proceedings of the Fourth Seminar of the Department of History. Addis Ababa: Addis Ababa University Press.

GEMEDA, G. (1984): Gomma and Limmu: The Process of State Formation among the Oromo in the Gibe Region, C. 1850-1889. M.A. thesis. Addis Ababa: Addis Ababa University.

GIST, N. P. - HALBERT, L. A. (1956): Urban Society. New York: Thomas Cromcull Company.

GONZÁLES-RUIBAL, A. (2011): Fascist Colonialism: the Archeology of Italian Outposts in Western Ethiopia (1936-1941). In International Journal of Historical Archeology 14, 4, pp. 547-574. 
GOSHU. H. (1970): The Kingdom of Abba Jifar II: 1861-1934. B.A. thesis. Addis Ababa: Haile Sellassie I University.

GRUHL, M. (1932): The Citadel of Ethiopia, The Empire of the Divine Emperor. London: Jonathan Cape.

GWYNN, C.W. (1911): A Journey in Southern Abyssinia. In Geographical Journal 37, 2, pp. 113-139.

HASSEN, M. (1990): The Oromo of Ethiopia. A history 1570-1860. Cambridge: Cambridge University Press.

HODSON, A. W. (1970): Seven Years in Southern Abyssinia. Westport: Negro University Press.

KRETZMANN, P. E. (1900): John Ludwig Krapf. The Explorer-Missionary of Northeastern Africa. Columbus: The Book Concern.

LEWIS, H. S. (1965): A Galla Monarchy, Jimma Abba Jifar, Ethiopia 1830-1932. Madison and Milwaukee: University of Wisconsin Press.

LITTLE, K. (1974): Urbanization as a Social Process: An Essay on Movement and Change in Contemporary Africa. London, Boston: Routledge and Kegan Paul.

MABOGUNGE, A. L. (1968): Urbanization in Nigeria. London: University of London Press.

MAINS, D. (2012): Blackouts and Progress: Privatization, Infrastructure, and a Developmentalist State in Jimma, Ethiopia. In Cultural Anthropology 27, 1, pp. 3-27.

MASSAJA, G. (1889): I Miei Trentacinque Anni Di Missione Nell' Alta Etiopia. Milan: Pontificia S. Guiseppe.

McCANN, J. C. (1995): People of the Plow. An Agricultural History of Ethiopia, 18001990. London: University of Wisconsin Press.

MONTADON, G. (1912): A Journey in South-Western Abyssinia. In Geographical Journal 40, 4, pp. 372-391.

NASSIR, M. (1973): Economic History of Jimma Aba Jifar 1878-1930. B.A. thesis. Addis Ababa: Haile Sellassie I University.

NEUMANN, O. (1902): From the Somali Coast through Southern Ethiopia to the Sudan. In Geographical Journal 20, 4, pp. 373-398.

PANKHURST, R. (1968): Economic History of Ethiopia. Addis Ababa: Artistic printers.

PANKHURST, R. (1982): History of Ethiopian Towns. From the Middle Ages to the Early Nineteenth Century. Wiesbaden: Franz Steiner Verlag.

DOI: 10.2478/eas-2018-0003 C University of SS. Cyril and Methodius in Trnava. All rights reserved. 
SALVADORE, M. (2010): The Ethiopian Age of Exploration: Prester John's Discovery of Europe, 1306-1458. In Journal of World History 21, 4, pp. 593-627.

SBACCHI, A. (1985): Ethiopia under Mussolini: Fascism and the Colonial Experience. London: Zed Book Ltd.

SEMMA, T. (2007): Origin and Development of Jimma Town to 1942. Master thesis, Addis Ababa University.

TRAVERSI, L. (1888): Escursione nel Gimma. In. Bollettino della Società Geografica Italiana, Serie III, Vol. I (Anno XXII - Vol. XXV), pp. 907-910.

VANDERHEYM, J.-G. (1896): Une Expédition avec le Négous Menelik. Paris: Librérie Hachett.

WOLDE MARIAM, T. (1984): Slavery and the Slave Trade, in the Kingdom of Jimma, 1800-1935. M.A. thesis. Addis Ababa: Addis Ababa University.

WOLDE MICHAEL A. (1973): Urban Development in Ethiopia: 1889-1925. In Journal of Ethiopian Studies 11, 1, pp. 1-4.

ZEWDE, B. (1991): A History of Modern Ethiopia, 1885-1974. London James Currey. 